\title{
Subcutaneous fat calcinosis in adult-onset dermatomyositis
}

\author{
Raj Shah, ${ }^{1}$ Spencer Ellis ${ }^{2}$ \\ 1Department of Gastroenterology and Hepatology, North Central Thames Foundation School, Stevenage, UK; \\ ${ }^{2}$ Lister hospital, Stevenage,Hertfordshire, UK
}

Correspondence to Dr Raj Shah, raj.shah@doctors.org.uk

\section{DESCRIPTION}

Calcinosis is a well-documented manifestation seen in up to $40 \%$ of patients with juvenile dermatomyositis. It is an uncommon feature in adult-onset dermatomyositis. ${ }^{1}$ We present a rare occurrence of calcinosis with unusual distribution in a 51 -year-old male.

18-months after diagnosis, our patient was seen in clinic following an episode of cellulitis. His muscle weakness and skin rash had responded well to steroid and oral methotrexate therapy. Examination identified a hard, irregular and extensive mass palpable across the abdomen. Laboratory studies revealed normal renal function, with creatine kinase elevated at 440 IU/1. Serum calcium, phosphate, parathyroid hormone and vitamin $\mathrm{D}$ were all within normal parameters. Malignancy was considered but the mass did not correspond to a specific abdominal organ. Due to the patient's body weight of $170 \mathrm{~kg}$ ultrasound assessment was limited.

An abdominal CT scan (figure 1) identified extensive calcification in the subcutaneous fat overlying the anterior abdominal wall and buttocks, with normal intra-abdominal viscera.

Despite this development, the patient demonstrated clinical improvement in his muscle power and skin rash. Consequentially, no change in the patient's management was made.

Calcinosis of the skin and muscle is unusual but recognised findings in adult-onset dermatomyositis, which typically have a predilection for sites of trauma. ${ }^{2}$ Other causes of ectopic calcification such as hyperparathyroidism, hypervitaminosis $\mathrm{D}$ and nephropathy were excluded by relevant investigations.

We demonstrate fascinating images illustrating the development of exclusive subcutaneous fat calcinosis, also known as calcinosis universalis ${ }^{3}{ }^{4}$ a phenomenon that is only rarely reported in adult-onset dermatomyositis.

Competing interests None.

Patient consent Obtained.
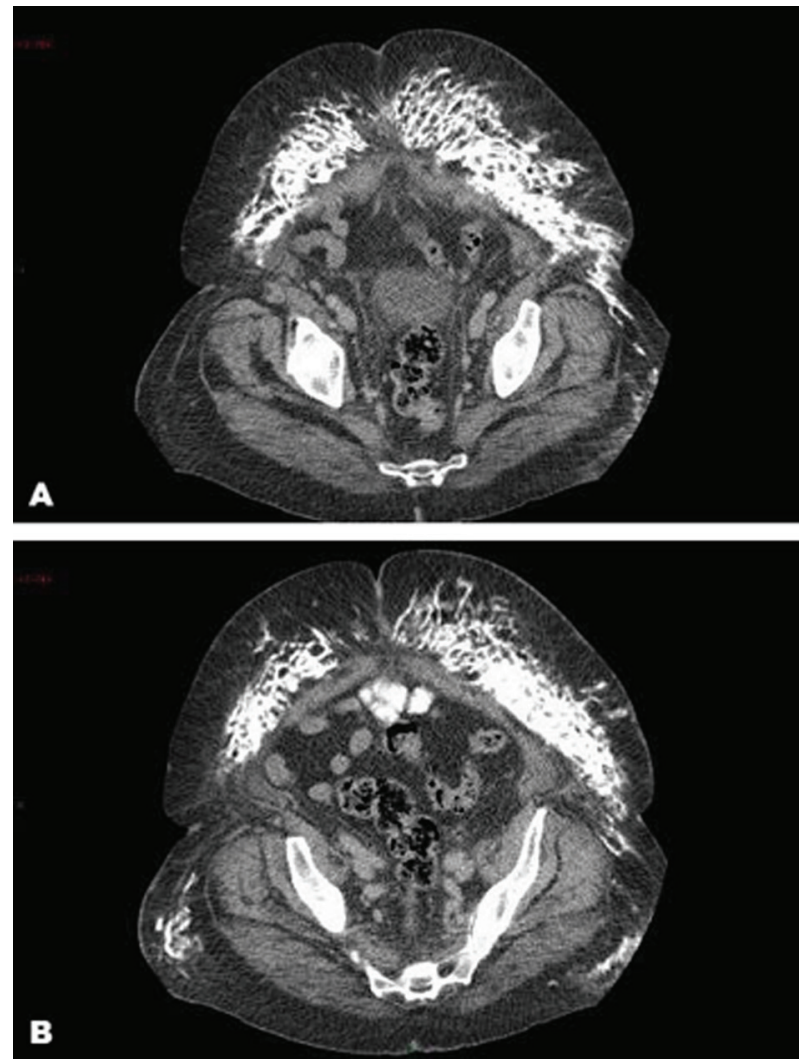

Figure $1(A, B) C T$ imaging delineating calcification within the soft tissues of the abdomen, with unremarkable changes in the remaining intra-abdominal viscera.

\section{REFERENCES}

1. Callen JP. Dermatomyositis. Lancet 2000;355:53-7.

2. Agarwal V, Sachdev A, Dabra AK. Case 104: calcinosis in juvenile dermatomyositis. Radiology 2007;242:307-11.

3. Santili C, Akkari M, Waisberg G, et al. Calcinosis universalis: a rare diagnosis. $J$ Pediatr Orthop B 2005;14:294-8.

4. Ogretmen Z, Akay A, Bicakci C, et al. Calcinosis cutis universalis. J Eur Acad Dermatol Venereol 2002;16:621-4. 


\section{BMJ Case Reports}

This pdf has been created automatically from the final edited text and images.

Copyright 2011 BMJ Publishing Group. All rights reserved. For permission to reuse any of this content visit http://group.bmj.com/group/rights-licensing/permissions.

BMJ Case Report Fellows may re-use this article for personal use and teaching without any further permission.

Please cite this article as follows (you will need to access the article online to obtain the date of publication).

Shah R, Ellis S. Subcutaneous fat calcinosis in adult-onset dermatomyositis. BMJ Case Reports 2011;10.1136/bcr.05.2011.4268, date of publication

Become a Fellow of BMJ Case Reports today and you can:

- Submit as many cases as you like

- Enjoy fast sympathetic peer review and rapid publication of accepted articles

- Access all the published articles

- Re-use any of the published material for personal use and teaching without further permission

For information on Institutional Fellowships contact consortiasales@bmjgroup.com

Visit casereports.bmj.com for more articles like this and to become a Fellow 